Ute Schmidt

\title{
Germans in Bessarabia: historical background and present-day relations
}

\begin{abstract}
This article provides a history of the experiences of German settlers in Bessarabia, now divided between modern-day Moldova and Ukraine. German influence in the area stems back to the activities of the Russian Tsar Alexander I, who offered German settlers the opportunity to locate in the area in the early nineteenth century, providing them with a range of privileges and freedoms. Despite the initially tough living conditions, as well as the ending some time later of some of the privileges and freedoms, the branding of the community as an 'enemy within' during the First World War and the subsequent occupation of the region by the Romanian army, the population grew to a figure in excess of 80000 and a prosperous community of more than 150 German municipalities developed until it was evacuated in 1940 after the signing of the Molotov-Ribbentrop Pact. Today, historic-cultural networks operate which seek to provide a friendly link, as well as restoration, relief and aid projects, between the citizens of the area today and the descendants of the German settlers.
\end{abstract}

Keywords: Bessarabia, Russian Empire, German colonists, serfs, peasants, Romanian occupation, First and Second World Wars, Molotov-Ribbentrop Pact, sovietisation, Landsmannschaft, EU enlargement, Moldova, Ukraine.

\section{German colonists in 19th century Bessarabia}

The Russian Empire expanded southward in the $18^{\text {th }}$ and 19th century, after Russian armies conquered large swaths of the steppe regions on the north coast of the Black Sea. When the Ottoman Empire was defeated in the fifth Russo-Turkish War in 1812, the strategically important region between the rivers Dniester and Prut came under Russian control. According to the Treaty of Bucharest (16 May 1812), the Turks had to cede the eastern part of Moldavia, which was then dominated by the High Porte, to the Tsarist Empire. The Ottoman Empire, moreover, lost South Bessarabia, which it had annexed as early as 1538 . Consequently, the complete Black Sea coast to the Prut River and the Danube delta came under Russian rule. The Russian administration gave the youngest, smallest and westernmost province of the new Russia the name 'Bessarabia,' adopting a term which, all the way into the $19^{\text {th }}$ century, had historically been used to denote merely the southern strip of this 'mesopotamian' region (Basarabia, i.e. the land of the Wallachian House of 'Basarab'). Alluding to older terminology, central and northern Bessarabia were also called 'Russian Moldavia' after 1812, while the Cuman-Tatar-Turkish term 'Budjak' (i.e. corner, triangle) survived for southern Bessarabia. 
After 1812, the Budjak became the central region for German settlement in Bessarabia. Contrary to central and northern Bessarabia, which were inhabited predominantly by Moldavians and dominated by boyars and orthodox clerics, the south of Bessarabia was largely depopulated once the Turkish military and the Nogai Tatars had withdrawn. The fallow, yet fertile, steppe was now ready for settlement by Russian, Moldavian and Ukrainian peasants. In addition, to further economic development, the Russian colonisation authorities renewed their efforts to recruit colonists from abroad.

Pursuing Napoleon's defeated Grande Armée on its retreat through Poland, Tsar Alexander I, a grandson of Catherine II, noticed the dismal conditions in which German settlers in the former Duchy of Warsaw had to live. Among these settlers were many Swabians, but also Prussians, Mecklenburgians, Palatines, Saxonians and others who had come to this region in the course of the Frederician colonisation as a consequence of the 'Partitions of Poland.' Alexander offered them to settle in Bessarabia. In his decree of 29 November 1813, he 'forever' guaranteed those willing to relocate a range of privileges and freedoms. Among the most important were a piece of land larger than sixty hectares, support with establishing farms, exoneration from military service and self-determination in religious matters.

A second large migration movement began around 1816/17, when the emigration prohibition in the absolutist kingdom of Württemberg was lifted. Thousands of emigrants from south-western Germany set out on a journey to southern Russia - either on the Danube in small boats called Ulmer Schachteln (Ulm boxes) or by the overland route through Bohemia and Galicia. This mass exodus was caused not only by political oppression in south-western Germany, but also by the hunger crisis of 1815-16. Religious motives played an important role as well in making the decision to emigrate towards the east: the so-called 'chiliasts,' who expected the End of Days to arrive soon, flocked to Mount Ararat in the Caucasus to prepare for the Second Coming and Christ's thousand-year rule. Many pietists and 'separatists' had been plunged into substantial conflict with church and state authorities over bitter quarrels about the imposed liturgy for baptism and the new hymn book. Catholic dissidents surrounding the charismatic revivalist preacher Ignaz Lindl left Bavarian Swabia, where they no longer felt at home.

By 1828, altogether around 10000 people of German, Swiss or Austrian descent had been registered in southern Bessarabia.

Despite the privileges promised by the Russian state, the living conditions for German newcomers in Bessarabia were extremely tough because the colonial administration had not sufficiently prepared the new settlements. There was a lack of basic equipment, above all shelter, building materials and foodstuffs, while corrupt low public officials grew rich taking the money promised to the settlers by the crown and, in some places, practising a regime of brutal punishment. Weakened by the strenuous journey and the miserable living conditions, a good third of all immigrants died shortly after arriving or during the first winter. Epidemics, cattle diseases and locust plagues, as well as repeated crop failures and the burdens of war, kept wrecking the colonists' efforts during the first period of settlement. It was only in the middle of the $19^{\text {th }}$ century that an economic upswing became apparent. The population grew and new daughter colonies were founded. In the history of Germans in Bessarabia, which comprises no more 
than five or six generations, a prosperous community of more than 150 German municipalities developed until the German population was evacuated in 1940.

It was characteristic of how the Germans settled in Bessarabia that they did not live in one large enclosed area of settlement, but as small minorities in the middle of Bessarabia's great variety of ethnic and religious communities. For the most part, they lived in quite homogeneous German communities in friendly neighbourhood with Moldavians, Bulgarians, Gagauz, Ukrainians, Russians, Lipovans, Jews, Armenians and other groups. In bigger market towns, like Tarutino, Sarata and Arzis, the population was more ethnically mixed. However, despite a natural manner of dealing with one another and a willingness to exchange goods and to co-operate with members of other ethnic groups, 'mixed marriages' were rare. The reason for this lay not so much in ethnic differences but rather in the group consciousness conveyed by church and denomination. Incidentally, not only the Germans but also the other ethnic groups in the 'multiculture' of Bessarabia followed this practice.

The following table shows the numerical ratio of nationalities in Bessarabia based on the census of 1930:

Table 1 - Population in Bessarabia, 1930

\begin{tabular}{|l|c|}
\hline Ethnic and religious groups & Number of people \\
\hline Romanians (Moldavians) & 1610757 \\
\hline Russians & 351912 \\
\hline Ukrainians & 314211 \\
\hline Jews & 204858 \\
\hline Bulgarians & 163726 \\
\hline Gagauz & 98172 \\
\hline Germans & 81089 \\
\hline Gypsies ${ }^{1}$ & 13518 \\
\hline Other & 26159 \\
\hline Total & 2864402 \\
\hline
\end{tabular}

\section{The settlement of German colonists in Bessarabia as a social pilot scheme}

At the beginning of the 19th century, the Russian colonisation policy introduced by Catherine II was revised by her successors, Paul and Alexander I. Promoting economic productivity and expansion on the land, which altogether became scarcer, took priority over massively populating empty steppe regions. The number of immigrants was reduced and they had to bring useful qualifications. Experienced craftsmen, peasants and wine-growers, families fit for work and 'respectable people' were supposed to use their

1 This term was used by various groups to identify themselves. 
knowledge and skills to serve as an example to the native rural population and thus become a modernising element in the backward agrarian society of Russia.

In the interest of their colonial aims, the Russian government granted the immigrants further privileges besides those mentioned above. For the benefit of the colonists' communities, they were not subordinate to the general Russian bureaucracy, which was often ineffective and corrupt, but to a state administration that had been solely created for this purpose. In 1818 the Ausländerkontor (Foreigner Office) was replaced by the Fürsorgekomitee für die ausländischen Kolonisten Südrusslands (Welfare Committee for the Foreign Colonists of South Russia), which served as a supervising control organ and actively furthered the economic and social development of German colonists in Bessarabia until 1871. The Welfare Committee was responsible not only for the German but also for all the southern Russian colonies. Besides German and Swiss colonists, the Russian colonial authorities had settled other ethnic groups here as well (Bulgarians, Russians and others), some of whom received full colonist status, others privileges that had been modified in some way.

In the society of the autocratic Tsarist Empire, where Russian peasants were freed from serfdom only from 1861 onwards, the colonists assumed the role of 'substitute peasants.' As it were, they were participants in a large-scale 'pilot scheme,' for their example was supposed to demonstrate that free and independent peasants could produce more wealth than oppressed serfs. The prosperous colonies should at least form 'comforting seeds' that would encourage the long-overdue reforms in Russia's agrarian sector. Far-sighted public officials in Russian service who adhered to progressive ideas (such as, for instance, the Westphalia-born Samuel Kontenius) were careful to ensure that the municipal-agrarian constitution would set up a sort of corset for the colonies, strengthening both the settlers' individual motivation for accomplishments and social cohesion in the rural communities. Due to their quasi-democratic principles, this constitution and further regulations determining local government, which gave independence and self-responsibility to the rural communities, laid the foundation for a small 'colonial republic' in the midst of Russian feudal rule.

The Russian authorities' demands on the colonists concerning their performance and conduct essentially corresponded to the attitudes which most German immigrants in Bessarabia had brought with them from the religious-cultural background of their old homes. This interweaving of Russian modernising policy and pietistic morals created central ideas, patterns of orientation and behaviours that left their mark on the way of life and mentality of German colonists in Bessarabia and contributed considerably to the prosperity of their communities. The 'Protestant Ethic' was the guiding principle for the organisation of community and individual life. A lifestyle agreeable to God required - besides prayer and other religious practices - a strong work and professional ethos, trying hard to be moral and compassionate, and an inner-worldly asceticism in connection with virtues like honesty, humility and thrift, as well as accomplishment and a striving for education. The identification with the role of a positive example ascribed to the settlers by the colonial administration was internalised over many generations and became deeply seated in the self-image of Germans in Bessarabia.

Applying a term by the French sociologist Pierre Bourdieu, I call this specific mental shaping 'cultural capital.' The importance of the German elementary school system 
and the early opening of a German institution for the training of teachers in the community of Sarata in 1844 are an example of this. The Wernerschule (Werner school), named after the Württembergian trader Christian Friedrich Werner, a friend of Ignaz Lindl's who founded the school, was not only the first German teaching school which led the way in all of south Russia, but it was also the first institution for the training of teachers to be officially confirmed in the whole Russian Empire. In contrast to the Russian institutions, which were founded later and run by the state, the protestant Werner school was primarily financed from resources raised by the German colonists themselves. It did not lose its independence until 1940. The Germans in Bessarabia owed it to this institution that they had well-trained teachers and that the value of school education in the communities was generally increased.

Religious conservatism and economic modernisation did not conflict in the German colonists' society in Bessarabia because the colonists' pioneer spirit required them to be open to agricultural and technical innovation. Sectarian constraints or collective ideologies proclaiming anti-modern isolation - which, for instance, the Hutterites and the Amish developed in North America - could not gain acceptance in Bessarabia. Despite the strong influence which spiritualistic religious tendencies were able to gain for some time, pietistic and sober, pragmatic forces always retained the upper hand. In a rural culture that was deeply rooted in Pietism - due to the short span of settlement of Germans in Bessarabia an urban bourgeoisie could not develop - priests, teachers and other academics and dignitaries assumed leadership roles.

In 1871 the Welfare Committee was dissolved and the colonists' privileges were abolished. Shortly afterwards, a first wave of Bessarabian Germans emigrated overseas, primarily because their exoneration from military service had been abolished in 1874 and the colonists saw this as a violation of the decree issued by Alexander in 1813 . Later, state intervention - now influenced by Pan-Slavism and Russian nationalism aimed at imposing economic and cultural restrictions on the minorities. Nonetheless, the Germans in Bessarabia were able to a large extent to retain their local and cultural autonomy until the First World War broke out. It was only when expropriation acts were passed on 2 February 1915, when speaking German in public was forbidden, German schools were closed, a prohibition on delivering sermons enacted and deportation prepared in the winter of 1916-17, that they suddenly became conscious of how their existence was threatened. Once called for as colonists by the Tsar, the Germans were now generally branded as an 'enemy within'. In January 1917, they were planned to be deported to Siberia and it was only the severe winter and the outbreak of the February Revolution that prevented these plans from being carried out.

\section{The inter-war period and German resettlement in the autumn of 1940}

When the First World War had ended, and after a phase of political and social unrest, Bessarabia came under Romanian rule. The endeavours to gain territorial and political autonomy for the country were bound to fail as Romanian troops invaded the region in January 1918.

After imminent expropriation and deportation had been averted, continuity seemed to be secured for the group of ethnic Germans in their familiar surroundings. However, political, economic and social upheaval after the First World War on the one hand, and 
the abrupt removal of Bessarabia from its close integration into the south Russian area of settlement on the other, caused considerable changes in all areas of life. The Dniester became an impassable border, traditional economic ties were cut and access to important trading centres, e.g. the port of Odessa, was blocked. New markets had to be opened up and new products and new sales strategies developed. In addition, landed property of more than 100 hectares was expropriated in the course of Romanian land reform. So-called 'hectare communities' were installed on the seized property. However, the farms in these communities, about six hectares in size, were often hardly big enough to provide families with a bare subsistence. There were also big cutbacks in cultural areas, in particular in the school system. The church-community schools were nationalised, as the Ministry of Education intensified its course of 'Romanianisation' during the twenties and thirties, and, in view of the restrictive minority policy pursued by the Romanian government, the German minority felt that their cultural autonomy was increasingly threatened. It was only shortly before they were evacuated that, by royal decree, the German communities were given back expropriated school buildings so that most of the German schools could reopen as church schools.

In the autumn of 1940, the history of German settlement in Bessarabia came to an abrupt end. The precondition for this was the Molotov-Ribbentrop Pact, signed one week before the German invasion of Poland, on 23 August 1939. In the 'secret protocol' included in the Pact, the Nazi government and the Stalinist Soviet Union divided central and eastern Europe into respective spheres of interest, the German party declaring its 'complete disinterest' in Bessarabia. After that, it was only a matter of time before Bessarabia was incorporated into the Soviet sphere of influence.

On 26 June 1940, the Soviet Union gave the Romanian government an ultimatum to withdraw its troops and administration from Bessarabia and northern Bukovina. Three days later, the Red Army took hold of these regions. On 5 September 1940, a German-Soviet agreement on the resettlement of German minorities was signed in Moscow. In mid-September 1940, a mixed German-Soviet commission arrived in Bessarabia. Its purpose was to organise the population's transfer and to evaluate the assets left behind by those about to be resettled so that they could be compensated later. On the German side, the resettlement was organised by the Volksdeutsche Mittelstelle (Liaison Office for Ethnic Germans) which had, since 1939, been integrated into the apparatus of the Reichskommissar für die Festigung deutschen Volkstums (Reich Commissioner for the Strengthening of Germandom) under Heinrich Himmler, the Reichsführer-SS (leader of the SS) and Chief of the German Police. On the Soviet side, the Council of People's Commissars decided on the matter. Personnel to carry out the resettlement were provided by the People's Commissariat for Internal Affairs (NKVD), i.e. by the secret police, and by the People's Commissariat of Defence.

In principle, resettlement was voluntary for the German population in Bessarabia, yet effectively there was no real alternative. During the Russian occupation, Germans were generally treated correctly as per contract by members of the Red Army. In bigger villages and towns, however, they noticed how people of other nationalities were taken away for interrogation by NKVD commandos and often did not return. Such impressions of political oppression and the perceptible changes in everyday living conditions made even the older people, who naturally found it hardest to part with their homes, 
realise that the Soviet invasion had brought the end of German colonisation in Bessarabia. The German minority therefore almost completely registered for resettlement. Around 93500 persons were relocated. Only about 2000 people stayed, most of them for family reasons. After disembarking on the Danube, the Bessarabia Germans were initially placed in about 800 temporary camps in the so-called Altreich, i.e. core Germany, in Austria and in the Sudetenland. Treated as a 'mass' that could be relocated within the context of Nazi settlement policy, Nazi population engineers later settled them in the new Reichsgaue Wartheland and Danzig-West Prussia in occupied Poland. In January 1945, the resettlers from Bessarabia, as did millions of refugees from other regions, fled westward to create a new life for themselves in post-war Germany.

\section{Bessarabia after German evacuation (1940-1945)}

Immediately after the Red Army's invasion of Bessarabia, the Soviets installed their repressive apparatus. The resettlers had seen only the first signs of a first wave of political persecution, which reached its climax in the summer of 1941. Prisons were filling up, while the Soviet organs also started a number of deportation campaigns to get rid of supposed and real political opponents, as well as disliked persons, groups and whole social strata. In one major operation in June 1941 alone, around 30000 'antisoviet elements' were detained and, for the most part, deported to Siberia.

After the Germans had been resettled, the Soviet authorities expended immense effort to push ahead with the sovietisation of Bessarabia. At the end of 1940, three sovkhozes and 14 kolkhozes had already been installed on the former German estates in the Moldavian SSR, which had been founded in the meantime. In December 1940, altogether 2500 poor farms from other districts and provinces were decided to be resettled in the new kolkhozes. Until the new inhabitants arrived - most of them were brought to Bessarabia from Soviet Ukraine and the heart of the UdSSR - temporary workers looked after the German property and tended to the abandoned livestock. The new immigrants received only residential buildings and working quarters, a few fixtures, livestock and fodder, while the technical equipment taken over from the Germans was entirely given to the Machine and Tractor Stations and the sovkhozes. It is not surprising that the German settlements decayed rapidly in the course of this fundamental transformation.

Immediately after the German invasion of the Soviet Union, Bessarabia returned under Romanian rule. The fascist regime of Ion Antonescu drove the Jewish inhabitants of Bessarabia and Bukovina to Transnistria, where they had to live in conditions unfit for human beings. Two-thirds of approximately 150000 deportees perished due to hunger and sickness. In 1944/45, after Bessarabia had been ravaged by the Second World War, it was incorporated into the Moldavian and the Ukrainian Socialist Soviet Republics and the Soviet government continued the process of political and economic transformation begun in 1940.

\section{Historic-cultural networks: potentials and current perspectives}

Today, the former area of settlement of the Bessarabian Germans is divided into two parts, one belonging to the Republic of Moldova, the other to Ukraine. For many years, 
in particular since the upheaval in the Soviet Union at the end of the 1980s, hundreds of Bessarabia Germans, also from younger generations, have been coming to the former settlements on the Black Sea coast every year. The local residents welcome them with open arms and without resentment. The reasons for these memorial journeys are manifold. Some of those who experienced the resettlement themselves still know enough Russian or Romanian to communicate and often they meet old acquaintances. Younger generations find ways personally to connect to today's inhabitants and they gain an insight into the region's political and economic conditions which probably would not be accessible to them in other ways.

One motive of which 'homeland tourists' are often accused is certainly not at play here: Bessarabia Germans and association officials have never expressed a desire to return to their former homes, nor have they demanded compensation from today's inhabitants. After all, the Germans had - though with a heavy heart - consented to being resettled in the autumn of 1940 and hardly any of the resettlers would have wanted to exchange places with those inhabitants that stayed. Therefore, history gives no grounds for hurt or animosity. In any case, it was only in the second half of the 1940s, after the Germans had been evacuated, that a considerable part of today's population came to Bessarabia in the course of Stalin's settlement policy.

Unhampered by historical resentment, friendly relations with today's inhabitants and representatives of local authorities could thus develop in many cases. On this halfofficial basis, a wide range of initiatives and concrete aid programmes, which state institutions would barely have been able to achieve, have been set up in the meantime. As part of the 'Bessarabia Relief' programme, the Landsmannschaft (an association of Bessarabia Germans) has co-ordinated the provision of hospitals with badly-needed equipment and medicine, they have supported schools and children's homes and they have organised the collection of clothing and other in-kind donations. Numerous transports carrying relief supplies have been arranged and brought to Ukraine and the Republic of Moldova, often in spite of considerable bureaucratic problems. Many younger Bessarabia Germans participate in organising such deliveries because they see such concrete action as a meaningful and practical way of fostering relations with the former homeland of their ancestors. Further projects consist of helping to improve the drinking water supply and others of a similar type.

Besides this charitable commitment, the number of initiatives interested in the history of the formerly German villages, and in reminding the public of the cultural institutions of former settlers, has been increasing since the 1990s. In unison with today's inhabitants, they have celebrated village anniversaries, erected numerous memorial stones and restored German cemeteries. There is a 'peasant museum' in Mirnopolje (Friedenstal), which illustrates how German colonists lived in Bessarabia prior to 1940. And in some places, publications and exhibitions focusing on the life of these Germans have been worked out.

The churches that have been restored in Sarata (in Ukraine, 1995), and in Albota (in Moldova, 2003), and how they were handed over to representatives of local denominations in ceremonial acts, are particularly impressive examples of the good relations. Besides, the repairs offered welcome employment opportunities to local crafts workers, who could thereby increase their income. The restoration of these formerly 
German churches was not only of a purely symbolic nature related to the cultural memory of Bessarabia Germans; the villages were also given back central semantic places with which today's inhabitants could identify.

Many young people in the Bessarabia of today, who know very little of the history of these places, have by now become very interested in learning the complete history of their country. And some of the 'uncharted territory' they encounter on the historical and political map of their homeland is connected with the history of the German minority. It would be desirable for the local intercultural exchange to be continued and intensified. However, opportunities for encounter should also be set up in other areas - for instance in science, education, media and other cultural institutions.

Understanding the respective historical experiences, getting to know the situation and mentalities of local residents, continuous human relations and mutual trust have so far laid the foundation for a sort of 'people's diplomacy from the bottom up.' The importance of such networks and historically-based cultural contacts has increased since the enlargement of the European Union towards the east. German politicians and official representatives of the Republic of Moldova and Ukraine also acknowledge this.

In his formal address to the Federal Meeting of Germans from Bessarabia on June 2008 in Ludwigsburg, German President Horst Köhler talked about the new Europe that had been created; that there were no more 'blank spots' on its maps. At last it was simply natural for visitors from former Bessarabia to be guests in Germany and, vice versa, for Bessarabia Germans to be welcome guests in their former homeland. He continued:

The example of the Republic of Moldova shows what an enormous adjustment the upheaval in the east of Europe, which was long under Soviet dominion, demands of the people. Moldova once was one of the richest republics in the Soviet Union; in the meantime, it has become the poorest country of Europe. That is why we should stand up and make sure that the enlargement of the European Community towards the east, which is both an important step and the right course to follow, does not create any new dividing lines, in particular with regard to the countries which today include parts of former Bessarabia. Europe does not end at the Ukrainian, nor at the Moldavian border! ${ }^{2}$

Köhler also conveyed the regards of the Moldovan President Vladimir Voronin to the Bessarabia Germans. Köhler said that Voronin had explicitly acknowledged the Germans' commitment to their old homeland and assured him that the Republic of Moldova:

Is preserving the remembrance and heritage of the Bessarabia Germans and will continue to do so.

2 Address given by Federal President Horst Köhler on the occasion of the 38th Federal Meeting of Bessarabia Germans on 1 June 2008 in Ludwigsburg; printed in: Mitteilungsblatt des Bessarabiendeutschen Vereins e.V. Vol 63 No 7, July 2008, pp. 7-9. 
The Ambassador of the Republic of Moldova, Igor Corman, also emphasised that Moldovans were particularly interested in good relations with Bessarabian Germans. He called them 'bridge builders', helping his country in its efforts to intensify relations with the Federal Republic of Germany and the European Union:

The relations with Germany are of great significance to us, also with regard to our endeavours concerning Europe. For that, we also think that contacts between citizens are very important. And the Bessarabia Germans, whom we view as a living bridge between our countries, have a special part in this. (...)

In particular, we admire them not only for setting up a dense network of contacts with the inhabitants of the Moldova of today, but also for contributing to the reconstruction of several churches. (...)

Preserving those cultural links and traditions supports the Republic of Moldova on its road into a European future. In this context I would argue that we need you, not only for cultivating such inestimable values as a sense of community and solidarity with your old homeland, but also for being an important element in the social fabric of our country. ${ }^{3}$

The Ukrainian consul general Yuriy Yarmilko, too, spoke of 'building bridges' and of his country's endeavours which, regarding foreign policy, were directed towards Europe:

Years ago, the Landsmannschaft of Bessarabia Germans set themselves a great task: building a bridge from Germany to the Ukraine that should make our peoples come closer together. Our peoples set a significant example of tolerance and life in a truly European spirit, the model for a future framework for lasting peace in Europe. The latest domestic and foreign dimensions of Ukrainian policy, which are directed towards Europe and which seek convergence with the euro-atlantic structures, are insistent proof of the fact that this country, which today includes parts of Bessarabia's territory, has increasingly moved into the focus of attention in European politics. The special skill of living in good neighbourly relations with members of other nationalities, as it worked so well in the past, has left its indelible mark on how the Ukraine leads multinational dialogues with other European countries.

Ukraine was presently going through 'troubled moments' but, nonetheless, he hoped:

That the extensive experience this group of Germans gathered living in close neighbourhood with other nations for a long span of time could be precious for building a European society together. ${ }^{4}$

3 See address given by Dr Igor Corman, Ambassador of the Republic of Moldova to the Federal Republic of Germany, printed in: Unvergessenes Bessarabien. Festschrift zum 38. Bundestreffen im Forum am Schloßpark in Ludwigsburg 2008, pp. 6ff.

4 Address by the Consul General of Ukraine, Yuriy Yarmilko, printed in: Mitteilungsblatt des Bessarabiendeutschen Vereins e.V. Vol 63 No 7, July 2008, p. 10. 
These statements demonstrate that leading political forces in post-communist Bessarabia prove to be open to close co-operation with the European Community. On the periphery of a Europe that is converging, both the Ukrainian government, a child of the 'Orange Revolution', and the leadership of the Moldovan Republic, formerly loyal to Moscow, are now working towards a long-term association with the European Union. The German government is an important partner in this and the Bessarabian Germans can forge strong links.

Private economic initiatives based in Germany are also welcome and have already begun to bear fruit in Bessarabia. A textile factory in Moldovan Cahul, for instance, produces goods for established German firms, thereby bringing about a visible economic upswing in the city. Reviving an older tradition, the Weleda company took fallow fields in the east of Moldova and, in 2000, there started cultivating organic lavender to produce essential oil. Today, the business comprises an area of 150 hectares and provides employment for 200 workers. Similar economic co-operation will probably be developed further and the experience, knowledge and connections of Bessarabian Germans might well be requested. Regarding their support for today's inhabitants of Bessarabia, whether in individual villages or on a regional level, Bessarabian Germans will have to adjust to a long-term perspective, however, since accession to the European Union, which both the Republic of Moldova and Ukraine are seeking, is not on the horizon for the time being.

\section{Recent publications on the subject of 'Germans from Bessarabia'}

Bessarabien. Deutsche Kolonisten am Schwarzen Meer Potsdamer Bibliothek östliches Europa - Geschichte. Potsdam: Deutsches Kulturforum Östliches Europa, 2008.

Die Deutschen aus Bessarabien. Eine Minderheit aus Südosteuropa (1814 bis heute), 3rd Edition, Cologne, Vienna, Weimar: Böhlau, 2006. 